\title{
Cancer employees and the right to fair labour practices in terms of the Labour Relations Act 66 of 1995
}

\section{Charles Maimela}

LLB LLM LLD

Senior Lecturer, Department of Private Law, University of Pretoria

\begin{abstract}
SUMMARY
Cancer is a medical condition that affects all of mankind and does not take into account the race, religion and socio-economic position of a person. The effect of cancer on people living with this medical condition goes beyond physical and psychological distress. This is because persons living with cancer experience discrimination in the workplace due to cancer and this affects the employment status or position of cancer employees. Cancer employees if they are not dismissed from work their working conditions is in most instances unbearable due to the unfair labour practices they experience at the hands of employers and fellow employees. Awareness about cancer in the workplace is encouraged and championed in this contribution as one of the measures to eradicate unfair labour practices that are experienced by cancer employees in the workplace.
\end{abstract}

\section{Introduction}

Employment is one of the most important socio-economic factors, which affect cancer patients. ${ }^{1}$ As a result of their condition, cancer employees are often victims of unfair discrimination in the workplace. ${ }^{2}$ In some instances, this may lead to affected employees losing their jobs, and consequently becoming economically dependent on family and friends. ${ }^{3}$

It is necessary to give special attention to the meaning of cancer and how it develops in the human body. Various unfair labour practices which cancer employees experience daily in the workplace will also be discussed herein. ${ }^{4}$ The relevant unfair labour practices, which will form part of this discussion, include: demotion, denial of promotion and unfair performance appraisals. These different forms of unfair labour practices will be explored with an aim of asserting that cancer does not necessarily deter an employee from working, despite its aggressive nature, and that in actual fact one can lead a normal and productive life in spite of having to live with cancer. For purposes of dealing with the research problem, one has to understand that cancer employees experience unfair

1 Doyal and Hoffman "The growing burden of chronic diseases among South African women" 2009 CME 458.

2 Doyal and Hoffman 2009 CME 458.

3 Doyal and Hoffman 2009 CME 458.

4 Doyal and Hoffman 2009 CME 459.

How to cite: Maimela 'Cancer employees and the right to fair labour practices in terms of the Labour Relations Act 66 of 1995 '2019 De Jure Law Journal 1-26
http://dx.doi.org/10.17159/2225-7160/2019/v52a1 
discrimination mainly because of the stigma attached to the disease and the ignorance exhibited by some employers and employees in relation to cancer. ${ }^{5}$ In addition, a comparative analysis between South Africa and England will also be explored due to the historical links both countries share. ${ }^{6}$ Reference will also be made, to the United States of America, as the United States, in general, has taken great strides in recognising the vulnerability of cancer employees and the need to protect the latter within the American legal system.

\section{The meaning of cancer}

As a point of departure, it is essential to look at the definition of the term "cancer". In the 12th century, Hippocrates also known as the "Father of Medicine" discovered cancer. ${ }^{7}$ Cancer is defined as a process where cells in the body grow in an uncontrollable way. ${ }^{8}$ The word cancer is derived from the Latin word "crab", which describes the way in which cancer spreads or appears in the human body, and which has a crab-like appearance. ${ }^{9}$ These include cancers from covering tissues, skin cancer, mucous membrane cancer and cancer from the glands. ${ }^{10}$ Further, the Regulations Relating to Cancer Registration, ${ }^{11}$ define cancer as all malignant neoplasms and conditions suspected to be such, as contained in the International Classifications of Diseases for Oncology. ${ }^{12}$ Another word used to describe cancer is "sarcoma" which is the type of cancer that targets supporting body structures such as the bones, tendons, muscles and fibrous tissues. ${ }^{13}$

From these definitions it becomes clear that cancer can spread through the human body to an extent where it is uncontrollable and unmanageable. One can be sure that cancer is indeed a very dangerous disease, which affects all of mankind without prejudice. ${ }^{14}$ However, because of its complex nature, new knowledge is discovered daily and

5 Amir, Neary and Luker "Cancer Survivors views of work three years post diagnosis: A United Kingdom perspectives" 2008 EJOJ 192.

6 Joubert et al, The Law of South Africa (2004) 8-9.

7 Barrow "Portraits of Hippocrates" 2001 Medical History 85-88.

8 Friedberg Cancer Answers (1993) 2.

9 David Cancer Care (1995) 2.

10 Scott 2.

11 Regulations Relating to Cancer Registration GN R380 in GG 34248 issued in terms of the National Health Act 61 of 2003 dated 26 April 2011.

$12 \mathrm{~S} 1$ of the Regulations Relating to Cancer Registration GN R380 in GG 34248 issued in terms of the National Health Act 61 of 2003 dated 26 April 2011.

13 Heney, Young and Dixon-Woods Rethinking Experiences of Childhood Cancer (2005) 21.

14 Carnevali and Reiner The Cancer Experience (1990) 1. Further, it is a reasonable argument and an unfortunate fact that nearly anyone across the globe has had his or her life touched by cancer to a lesser or greater extent, such as they themselves being affected by cancer directly; or indirectly, having a family member or loved one affected by cancer. Cancer is a disease that preys on all of us; both young and old people are affected. 
there is still a lot to be learned about cancer, both in the medical profession and society in general. ${ }^{15}$

\section{Cancer as a disability}

Depending on what kind of cancer a person suffers from, and the stage at which the cancer is diagnosed, it can result in a person experiencing either permanent or temporary disability. ${ }^{16}$ As such, it is important to explore the meaning of disability and link it to the medical condition of a cancer patient.

Disability can be defined as different functional limitations that occur in any group of people and in any country across the globe, and can be in the form of intellectual impairments, physical impairments, sensory impairments, medical conditions and mental illnesses; all of which can be temporary or permanent in nature. ${ }^{17}$

When dealing with the concept of disability, it is important to note that there are two schools of thought regarding the meaning of disability; namely the medical model and the social model of disability. ${ }^{18}$ The medical model of disability places emphasis on the medical condition or impairment of the person with a disability. ${ }^{19}$ For example, in the context of a cancer employee, the medical model focusses on the employee instead of focussing on the ability of the employee to do work. For this reason, the medical model of disability is criticised because it personalises disability and makes it the problem of the individual concerned, which can be solved through cure or treatment of that disability. ${ }^{20}$ The social model of disability is based on the notion that the adverse circumstances, which people with disabilities experience and the unfair discrimination which they are subjected to daily, do not emanate from their disability or impairment but emanates from society. ${ }^{21}$ In terms of this school of thought, society is characterised as being unable

Cancer holds no respect for national boundaries, ethnicity, race and social class because all of us are equal when it comes to the epidemic of cancer. Striking as much from within as without; cancer damages our individual and collective sense of health and well-being, and thus forms an integral part of our whole life. This is due to the fact that its human and economic effects are potent, measured each year in millions of productive years lost and billions of health care money spent. Cancer is a fearsome adversary, leaving tragedy in its wake; as we can see today cancer is the reason why millions of lives are lost annually. See Greenwald et al, Cancer Prevention and Control (2001) 9.

15 Carnevali and Reiner 2.

16 Carnevali and Reiner 3.

17 Article 17 of the UN Standard Rules on the Equalization of Opportunities for Persons with Disabilities Adopted by UN General Assembly Resolution 48/ 96 of 20 December 1993.

18 Olivier and Smit Labour Law and Social Security Law (2002) 230.

19 Olivier and Smit 230.

20 Olivier and Smit 231.

21 Chapter 1 of the White Paper on Integrated National Disability Strategy: The Social Model of Disability 1-2 1997. 
to accommodate people with disabilities; and disability is not seen as an inability, which takes away the affected person's ability to do work. ${ }^{22}$

The social model of disability is also known as the human rights model of disability, because it centralises the person with a disability and his or her human dignity as enshrined in the Constitution without any focus on the impairment. ${ }^{23}$ The social model to disability is in line with substantive equality and this has been affirmed by Ngwena, who argues that no country follows the social model to disability in its purest form, but both the medical and social model to disability are required when disability is interpreted for a better understanding. ${ }^{24}$ This view is correct because cancer can be construed in line with both the medical and social model of disability. The challenges which cancer employees experience in the hands of employers who view cancer as only a problem of the employee concerned, takes the form of a medical model to disability; whereas the myths and the stigma maintained by society about cancer which result in the discrimination of cancer employees, is in line with the social model of disability.

In South Africa, persons who suffer from unfair discrimination on grounds other than the ones listed in terms of the Employment Equity Act, must first of all convince the court that the unlisted ground on which they claim to be discriminated against affect them adversely or may potentially affect them in an adverse manner. Once the court is satisfied with this view then the affected employee will have to prove the alleged unfair discrimination on the basis of the unlisted ground. ${ }^{25}$ With regard to people who suffer from a progressive or recurring condition such as cancer, we follow the medical model and not the social model to disability. Ngwena argues that the non-recognition of progressive conditions such as cancer, which can leave a person with a temporary or permanent disability, makes a person vulnerable to discrimination in both society and in the workplace. ${ }^{26}$

Contrary to the South African approach, which places focus on persons with actual disabilities while neglecting those who suffer from progressive diseases such as cancer; in countries like England and

22 Chapter 1 of the White Paper on Integrated National Disability Strategy: The Social Model of Disability 1-2 1997.

23 S 10 of the Constitution of the Republic of South Africa, 1996. See Wookman, Roux and Bishop Constitutional Law of South Africa: Student Edition (2007) 35-38.

24 Ngwena "Interpreting Aspects of the Intersection between Disability, Discrimination and Equality: Lessons for the Employment Equity Act from Comparative Law. Part I (Defining Disability)" 2005 Stellenbosch Law Review 211.

25 S 6(1) of the Employment Equity Act 55 of 1998, prohibits unfair discrimination on the basis of race, sex, disability, religion, HIV status, culture and language in the employment context.

26 Ngwena 2005 Stellenbosch Law Review 230. 
America, cancer is recognised as a progressive condition, which constitutes a disability. ${ }^{27}$ More on the English and American approach will be covered later on in this paper. The approaches adopted in those countries are surely in line with the argument raised by Ngwena and Pretorius, that disability must be interpreted widely without imposing a substantial limitation requirement on people with disabilities, which tends to exclude those people who suffer from progressive conditions such as cancer. ${ }^{28}$ Cancer patients don't only suffer as a consequence of their disabilities being substantially limiting in themselves, but they suffer because of the approach which people adopt in their engagements towards people who have cancer. ${ }^{29}$ This is the common trend when it comes to the discrimination of cancer employees, because most of them are discriminated against unfairly in the workplace, not because they are unable to work but merely because they have cancer.

\section{Unfair labour practices and the right to fair labour practices}

The Constitution of the Republic of South Africa, 1996 (hereafter referred to as the Constitution), which guarantees the right to fair labour practices, and the Labour Relations Act which stipulates what constitutes unfair labour practices, brought certainty and stability to the meaning of unfair labour practices. ${ }^{30}$ In terms of section 23(1) of the Constitution, everyone has a right to fair labour practices, ${ }^{31}$ which means this is a right that is constitutionally entrenched and is thus given force by legislation.

Section 186(2) of the Labour Relations Act provides that unfair labour practices can only occur in the context of an employer-employee relationship and does not extend beyond this relationship. This means a job applicant who happens to have cancer, does not have a right to fair labour practices; which in turn means that unfair labour practices cannot be committed against an applicant, as he or she is not an employee. ${ }^{32}$

27 Blanpain 24.

28 Ngwena and Pretorius "Conceiving Disability, and Applying the Constitutional Test for Fairness and Disability: A Commentary on IMATU $v$ City of Cape Town" 2007 Industrial Law Journal 747.

29 Ngwena and Pretorius 2007 Industrial Law Journal 747-748.

30 S 23(1) of the Constitution of the Republic of South Africa, 1996 and see the court case of Kylie $v$ CCMA and others 201031 ILJ 1600 (LAC), where the court ruled that every person involved in a relationship of employment, including sex workers, regardless of the fact that sex work is still illegal under the South African law, has a s 23 constitutional right to fair labour practices and that this right involves at the minimum, being treated with dignity by employers.

31 S 23(1) of the Constitution of the Republic of South Africa, 1996.

32 S 186(2) of the Labour Relations Act 66 of 1995. Hoffmann $v$ South African Airways CCT 19/00 2000 ZACC 17; 2001 (1) SA 1; 200011 BCLR 1235; 200012 BLLR 1365 (CC). 
In South African Defence Force Union $v$ Minister of Defence, ${ }^{33}$ the Constitutional Court re-affirmed this principle when it held that the constitutional right to fair labour practices only goes as far as an employment relationship that is constituted in a contract of employment as well as a relationship akin to an employment relationship. Therefore, effect of this provision is that unfair conduct on the part of the employer that is prejudicial towards an employee will not permitted in an employment relationship, or a relationship equivalent to that of employment.

A job applicant who suffers from cancer is only protected from unfair discrimination in terms of the Employment Equity Act. ${ }^{34}$ The Employment Equity Act aims to promote economic development, social justice, labour peace and democracy in the workplace. ${ }^{35}$ It is apparent that a job applicant with cancer, who has been refused employment on the basis of his or her condition, has a leg to stand on, and can take the employer to court on the basis of unfair discrimination. ${ }^{36}$ This position was confirmed in the court case of Hoffmann $v$ South African Airways, ${ }^{37}$ in which an applicant was denied employment on the basis of his HIV/ AIDS status, as the conduct of the employer was found to be discriminatory towards the applicant and thus unlawful. ${ }^{38}$

Based on this assessment, a cancer patient applying for a job can rely on both the Employment Equity Act, and the Hoffmann $v$ South African Airways case, in raising an argument about unfair discrimination upon being denied a job on the basis of their health condition. ${ }^{39}$ This is significant in our legal system because job applicants, particularly those affected by health deformities such as cancer, are protected by the law with regard to their enjoyment of the right to human dignity and the right to choose a profession or an occupation. ${ }^{40}$

In the case of National Education Health \& Allied Workers Union $v$ University of Cape Town, ${ }^{41}$ it was stated that the right to fair labour practices is about the continuation of the relationship between the

33 South African Defence Force Union v Minister of Defence 19996 BCLR 615 (CC), this case dealt with the right of members of the South African Defence force to join a trade union as well as take part in collective bargaining. This was due to the fact that members of the defence force were restricted from joining a trade union as well as entering into collective bargaining, but this was declared unconstitutional by the court.

$34 \mathrm{~S} 2$ of the Employment Equity Act 55 of 1998.

$35 \mathrm{~S} 2$ of the Employment Equity Act 55 of 1998.

$36 \mathrm{~S} 2$ of the Employment Equity Act 55 of 1998.

37 Hoffmann $v$ South African Airways supra.

38 Hoffmann $v$ South African Airways supra.

39 Hoffmann $v$ South African Airways supra.

40 S 10 and S 22 of the Constitution of the Republic of South Africa, 1996.

41 National Education Health \& Allied Workers Union $v$ University of Cape Town 200324 ILJ 95 (CC). 
employer and the employee on terms that are fair towards both parties. $^{42}$ In this context, fairness will relate to both economic and societal factors such as health, safety, environment and the economy. ${ }^{43}$ This will surely make the right to fair labour practices more inclusive. Fair labour practices are not aimed at restricting the pursuit of gain on the part of employers, but instead are aimed at ensuring that a balance is maintained between the rights of employees and the right of the employer. ${ }^{44}$ The Labour Relations Act should facilitate the realisation of both the employer's and the employees' rights, as provided in terms of the law.

\section{Unfair labour practice in terms of the Labour Relations Act 66 of 1995}

Section 186(2) of the Labour Relations Act outlines what constitutes unfair labour practices in the workplace. ${ }^{45}$ Unfair labour practice refers to any unfair act or omission that arises between an employer and an employee involving the following matters:

(a) Unfair conduct by the employer relating to the promotion, demotion, probation (excluding disputes about dismissals for a reason relating to probation) or training of an employee or relating to the provision of benefits to an employee;

(b) The unfair suspension of an employee or any other unfair disciplinary action short of dismissal in respect of an employee;

(c) A failure or refusal by an employer to reinstate or re-employ a former employee in terms of an agreement;

(d) An occupational detriment, other than dismissal in contravention of the Protected Disclosures Act 26 of 2000, on account of the employee having made a protected disclosure defined in the Act.

It is important to define what promotion and demotion actually means as stated in the abovementioned provision because these are the unfair labour practices, which cancer employees may commonly experience in the workplace. ${ }^{46}$

42 National Education Health \& Allied Workers Union v University of Cape Town supra.

43 Vettori "The role of human dignity in the assessment of fair compensation for unfair dismissals" 2012 PER/PELJ 102.

44 Brassey et al, The New Labour Law (2007) 98.

$45 \mathrm{~S} \mathrm{186(2)}$ of the Labour Relations Act 66 of 1995. Further, please refer to section 1 of the Labour Relations Act 66 of 1995, which states that the purpose of this Act is to advance economic development, social justice and labour peace in the workplace.

46 Du Toit et al, Labour Relations Law: A Comprehensive Guide Sixth Edition (2015) 545, and please refer to Doyal and Hoffman 2009 CME 459. 


\section{Common law and statutory law provisions for promotion}

Under the common law, employees have no legal entitlement to be promoted to higher positions, unless the employees can prove that a contractual right thereto exists. In the case of employees in the public sector, if they are in a position to prove a legitimate expectation exists for them to be promoted, then they may assert such a right. ${ }^{47}$ Promotion or demotion granted under the common law fall squarely on executive prerogatives or the powers of the employer. ${ }^{48}$ However, in terms of Labour Relations Act, promotion is now considered as one of the grounds for unfair labour practices. ${ }^{49}$

Promotion refers to the change of the employee's terms and conditions of employment that result in material increase to the salary, responsibilities and status of the employee. ${ }^{50}$

Nel argues that promotion is based on merit and responsibility, as it is meant to enhance the development of the employee, while at the same time it is directed towards the interests of the company. ${ }^{51}$ From this reasoning one can surely argue that in order for an employee to be promoted, the employee must be qualified and competent enough to carry out the tasks expected of him or her in that particular position. Therefore, it is clear that promotion does not take into account the disability or health status of the employee in question because such concerns may not necessarily have a negative impact on the employee's

47 John Dismissal, discrimination and unfair labour practices (2008) 52.

$48 \mathrm{~S} 186(2)$ of the Labour Relations Act 66 of 1995. See Aries $v$ CCMA \& Others 200627 ILJ 2324 (LC) the court held that there are limited grounds on which an arbitrator, or a court, may interfere with discretion which had been exercised by a party competent to exercise that discretion. The reason for this is clearly that the ambit of the decision-making powers inherent in the exercising of discretion by a party (including the exercise of the discretion, or managerial prerogative, of an employer) ought not to be curtailed. It ought to be interfered with only to the extent that it can be demonstrated that the discretion was not properly exercised. The court held further that an employee can only succeed in having the exercise of discretion of an employer interfered with if it is demonstrated that the discretion was exercised capriciously, or for insubstantial reasons, or based upon any wrong principle or in a biased manner.

49 S 186(2)(a) of the Labour Relations Act 66 of 1995.

50 Martin Profiting from Multiple Intelligences in the Workplace (2001) 206. See further, the International Labour Organisation (ILO) 2009 ILO 2-3, which states that The International Labour Organisation, of which South Africa is a member, places an obligation on employers to provide career information to employees who suffer from disabilities or health deformities. The information must be accessible to these employees to ensure that they are well informed about the various opportunities which are available to them in the workplace. This duty also encompasses the duty to encourage the relevant employees to apply for promotions, particularly in cases where there is evidence that the employee would otherwise be reluctant to do so, on account of their state of health or disability.

51 Nel et al, Human Resources Management (2001) 272. 
ability to work. This argument is also expanded by O'Brian, who argues that disability or health status of an employee does not take away the competence of the employee although it can have an effect on the ability of the employee to do his or her work to a lesser or greater extent; and therefore this does not take away the right of the employee to be granted a promotion. 52

Grogan advances the argument that, for a cancer employee to succeed with a claim of unfair labour practice with specific reference to promotion, he or she must prove certain factors, which are burdensome due to the lack of recognition of cancer as either a disability or grounds of unfair discrimination. ${ }^{53}$ The employee must show that the employer has exercised his or her discretion capriciously, or for unsubstantiated reasons, or that the decision was taken based on a wrong principle or was even biased. ${ }^{54}$ Furthermore, Grogan states that employers can be held liable for unfair labour practice with regard to promotion, if they have created a reasonable expectation that the employee will be promoted, and then without adequate reasons frustrate the employee by refusing to grant the employee a promotion. ${ }^{55}$

If the employee is qualified and competent enough based on the requirements of the position, then there is no way that their health status or disability can be used as a justification to prevent the employee from being promoted. Should this be the case, then it will amount to an unfair labour practice in terms of the Labour Relations Act, and the onus of proving the unfair labour practice rests with the employee alleging the unfair labour practice. ${ }^{56}$ Based on this analysis, one can see the risk of employers possibly using the condition of cancer employees, as scapegoats to deny them promotion. Employers may attempt to do so due to the lack of a specific recognition of cancer as grounds of unfair discrimination because in effect, cancer employees may not seek to go through the burdensome process of having to show that unfair labour practices have indeed occurred, as illustrated by Grogan's view in the discussion above.

Furthermore, in the case where an employee is excluded from promotion due to disability and health deformities, it can be argued that this amounts to systematic discrimination; which is a combination of direct and indirect discrimination. ${ }^{57}$ Systematic discrimination in the employment context simply emanates from the established rules or procedures of recruitment, hiring and promotion; and which are not designed to promote discrimination. In this instance, the discrimination is reinforced by the exclusion of disadvantaged groups, because the

52 O'Brian Crippled Justice: The history of modern disability policy in the workplace (2001) 152.

53 Grogan Workplace Law (2009) 75.

54 Grogan 75.

55 Grogan 76.

56 S 186(2) of the Labour Relations Act 66 of 1995.

57 Hunter Indirect Discrimination in the Workplace (1992) 12. 
exclusion promotes the belief that they are incapable of qualifying for a promotion due to their state of health or disability. ${ }^{58}$ To combat or fight systematic discrimination is important for purposes of creating a working environment in which negative attitudes and practices are rightfully challenged and discouraged. ${ }^{59}$ The process in eliminating systematic discrimination in the workplace goes hand in hand with the obligations set by the International Labour Organisation as briefly discussed earlier, ${ }^{60}$ to ensure that those employees with disabilities and those who suffer from health deformities are well informed about the opportunities, which are available to them, and that they know their rights in the workplace. ${ }^{61}$

The case of Joint Affirmative Management Forum $v$ Pick $n$ Pay Supermarket, ${ }^{62}$ involved the promotion of staff members from being causal workers to becoming permanent employees, and thus the question at hand was whether this kind of change constituted promotion. The employer had a policy in place in which an employee would first be appointed as a causal worker and after a reasonable time, the employee would be appointed as a permanent employee. ${ }^{63}$ In this case, the Commission for Conciliation Mediation and Arbitration (CCMA) accepted the policy of the employer on the basis that such changes from a causal worker to a permanent employee with benefits amounted to promotion. ${ }^{64}$

The principle of promotion was furthermore considered in the court case of Department of Justice $v$ CCMA \& Others, ${ }^{65}$ in this case, the Department of Justice advertised vacant senior positions and both internal applicants, which are people who worked in the Department, and external applicants were invited to apply for this opportunity. ${ }^{66}$ This meant that the internal employees of the Department would compete with external applicants for the vacant positions. The internal employees of the Department held the view that if they were appointed for the advertised position it would not constitute promotion. ${ }^{67}$ However, the Labour Court held that if the internal employees of the Department were appointed for the advertised senior post, this would surely amount to promotion because they did not occupy the same rank or position as the ones advertised by the Department. The claim of the employees was thus dismissed by the Labour Court, on the basis that the conduct of the

\footnotetext{
58 Hunter 12-13.

59 Hunter 14.

60 Martin 207.

61 ILO 2009 ILO 2.

62 Joint Affirmative Management Forum v Pick n Pay Supermarket 199718 ILJ 1149 (CCMA).

63 Joint Affirmative Management Forum v Pick n Pay Supermarket supra.

64 Joint Affirmative Management Forum v Pick n Pay Supermarket supra.

65 Department of Justice v CCMA \& Others 20044 BLLR 297 (LAC).

66 Department of Justice $v$ CCMA \& Others supra.

67 Department of Justice $v$ CCMA \& Others supra.
} 
employer did not amount to unfair labour practices on the basis of promotion. 68

\section{Common law and statutory law provisions for demotion}

Demotion is the opposite of promotion. A demotion occurs in the case where there is a change in the employee's terms and conditions of employment that causes material reduction of the employee's responsibilities, remuneration and status. ${ }^{69}$ It is important to understand that in certain instances, a change in the work of an employee does not amount to demotion. For instance, if the employee experiences being placed in a slightly different work station where the scope of the work falls within the scope of the employees initial duties, or where the employer makes a change to the title of the employee's position. ${ }^{70}$ It must be noted that employees cannot be demoted from posts, which they were not formally appointed for. ${ }^{71}$

At common law, the demotion of employees without their consent amounts to a repudiation of a contract between the employer and the employee concerned. ${ }^{72}$ In this regard the demoted employee has the choice to either uphold the contract while instituting a claim for damages, or the employee can seek for an order to compel the employer to restore him or her to the original position. ${ }^{73}$ However, it is important to take into account the fact that in terms of section 186(2) of the Labour Relations Act an employer by implication is allowed to demote an employee, provided that this is done in a fair manner. ${ }^{74}$ The onus of proving that unfair demotion has occurred rests with the employee who alleges the unfair demotion on part of the employer. ${ }^{75}$

68 Department of Justice v CCMA \& Others supra.

69 Venter and Levy Labour Relations in South A frica Fifth Edition (2014) 248.

70 Du Plessis and Fouche A Practical Guide to Labour Law Eighth Edition (2015) 355, and please refer to Grogan 79.

71 Grogan 79.

72 Venter and Levy 249

73 Grogan 264.

74 S 186(2) of the Labour Relations Act 66 of 1995 and see the court case of In Nxele $v$ Chief Deputy Commissioner, Corporate Services, Department of Correctional Services \& others 200829 ILJ 2708 (LAC) the court considered whether the decision to transfer the employee temporarily to Pollsmoor constituted a demotion. It was held that the status, prestige and responsibilities of the position were relevant to the determination of whether or not a transfer constituted a demotion. In light of the detailed and uncontested evidence of the employee in regard to the status, prestige and responsibilities of his position in Cape Town, the court did not hesitate to conclude that that position was of a higher status and prestige and held greater responsibilities than the position he was to occupy at Pollsmoor. The employee's transfer to Pollsmoor therefore constituted demotion. Since the employee did not consent to the demotion, it was unlawful in terms of the common law and unfair in terms of the Labour Relations Act. Grogan 265. 
In Solidarity obo Kern $v$ Mudau \& Others, ${ }^{76}$ the concept of demotion was considered. This case involved an employee who was moved from the position of senior personnel officer to the position of committee officer after the restructuring process of the company of the employer, who is the respondent in the proceedings. ${ }^{77}$ The employee took the matter to arbitration, and the case was decided against him on the basis that the current position he was occupying was not different from the position he used to occupy initially. It was held that the change, which took place in his employment position, did not amount to demotion and that no unfair labour practice was committed against him. ${ }^{78}$ However, when the matter went to the Labour Court, the judge held that the employee was in fact demoted as he had fewer responsibilities in the present position and consequently received a lower salary, owing to the newly restructured position. ${ }^{79}$ The court held that the decision of the employer amounted to a demotion. The judge went further to state that the arbitrator was lacking knowledge as to what the concept of demotion entails. Accordingly, the company was ordered to compensate the employee for the loss he had endured due to the demotion, as well as the salary he was entitled to. ${ }^{80}$

Another case which deals with demotion is SA Police Services $v$ Salukazana and Others. ${ }^{81}$ In this case the employee was transferred to another area, and the transfer brought about change to the conditions of service of the employee. ${ }^{82}$ The transfer resulted in change of status of the employee, with regard to the position he occupied; and resulted in him having fewer responsibilities than before he was transferred to the new area. The Labour Court found that indeed the employee was demoted and the conduct of the employer amounted to unfair labour practice. ${ }^{83}$

76 Solidarity obo Kern v Mudau \& Others 20076 BLLR 566 (LC).

77 Solidarity obo Kern $v$ Mudau \& Others supra.

78 Solidarity obo Kern v Mudau \& Others supra.

79 Solidarity obo Kern $v$ Mudau \& Others supra.

80 Solidarity obo Kern $v$ Mudau \& Others supra. See the recent case on the aspect of demotion which is hidden under the aspect of transfer of an employee by an employer. In SA Police Services $v$ Salukazana \& Others 2010 31 ILJ 2465 (LC) the employee was notified by a letter headed 'lateral transfer' that he had been permanently transferred to a new position. The effect of the transfer was that although he remained on level 13 and his salary and benefits were not changed, his status had been diminished. In the past he reported to the area commissioner, in his new position he was expected to report to a person in a lower position than the area commissioner. The court found that demotion can manifest itself in many ways. It can arise through a reduction of salary, a change to terms and conditions of employment and a transfer. In fact, a demotion and a transfer have common attributes - there is a movement in both a demotion and a transfer. If the movement leads to a reduction in status, it is a demotion. Thus, if a transfer leads to a change in terms and conditions of employment which amounts to demotion, an employee is entitled to bring a claim relating to an unfair labour practice.

81 SA Police Services $v$ Salukazana and Others supra.

82 SA Police Services $v$ Salukazana and Others supra.

83 SA Police Services $v$ Salukazana and Others supra. 


\section{Workplace promotion and demotion in the context of cancer patients}

It is common for employers to engage in unfair labour practices by way of side-lining employees who suffer from cancer when it comes to considerations for promotion. ${ }^{84}$ Similarly, some employers end up demoting cancer employees due to the belief that once an employee is diagnosed with cancer, they are incapable of working in the same capacity as they were, prior to them being diagnosed with cancer. ${ }^{85}$ This is the kind of attitude and belief that must be discouraged, through educating the employer and fellow employees about cancer. ${ }^{86}$ Apparently in South Africa, employees who are mostly affected by the possibility of unfair dismissal as a result of cancer are those who are particularly suffering from breast cancer. ${ }^{87}$ This occurs as a consequence of the fact that breast cancer is a leading cause of death cancers and affects many employees in South Africa. ${ }^{88}$ In addition to the possibility of unfair dismissal, cancer employees may find themselves receiving unfavourable performance reviews. ${ }^{89}$ The unfavourable performance reviews are commonly caused by a lack of reasonable accommodation in the workplace, as this tends to make cancer employees look as if they are floundering in their jobs.

Reasonable accommodation means the duty of the employer to provide support to the employee by adjusting working conditions and hours of the employee. ${ }^{90}$ The duty is placed on employers to provide reasonable accommodation because it is a non-discriminatory mechanism in its constitutional form, and a juridical tool which is aimed at achieving substantive equality among people, ${ }^{91}$ and in this context, specifically cancer employees. Undoubtedly, the employer's duty is a measure of eliminating arbitrary unfavourable performance reviews because the working environment will be made conducive and productive for the cancer employee to work if this duty is fulfilled. ${ }^{92}$ Reasonable accommodation was also emphasised in the court case of MEC for Education, Kwazulu Natal $v$ Pillay, ${ }^{93}$ the Constitutional Court stated "reasonable accommodation requires that the employer must take positive measures such as removing access barriers, even if it means

84 Mehnert et al, "Employment challenges for cancer survivors" 2013 Cancer 2151-2152.

85 Mehnert et al, 2013 Cancer 2152.

86 Cooper, Low and Grunfeld 2010 Occupational Medicine 612.

87 Business Day (2010-04-13) 7.

89 Macmillian-Cancer-Support http://www.macmillan.org.uk/Cancerinforma tion/Livingwithandaftercancer/Workandcancer/Supportforemployees/Work cancer/Your\% 20rights/Protectionfromdiscrimination.aspx (accessed 201403-29).

90 S 15 (2) of the Labour Relations Act 66 of 1995.

91 Bernard "Reasonable accommodation in the workplace: To be or Not to be?" 2014 PER/PELJ 2871.

92 Cooper, Low and Grunfeld 2010 Occupational Medicine 612.

93 MEC for Education, Kwazulu Natal v Pillay 2008 1 SA 474 (CC). 
incurring additional hardships or expenses to ensure that all employees enjoy their right to equality". ${ }^{94}$ In light of the above, Bernard argues that the duty of reasonable accommodation on the part of employers may be both positive, such as making alterations to the working environment to enable the disabled employee to work; and negative, such as dismissing the disabled employee due to incompetence and in the interest of the company in order to achieve the right to equality of all employees in the workplace. ${ }^{95}$ However, Bernard cautions that such a duty on the part of employers to reasonably accommodate employees is not absolute, in the sense that no court can expect an employer to excessively incur expenses, if it cannot reasonably accommodate the employee due to his or her state of health. ${ }^{96}$ In this context, it is very clear and important that more education and communication about cancer is required in the workplace, as well as the amendment of policies in the workplace can work. ${ }^{97}$

Brassey argues that the restriction of unfair labour practices is not designed to restrict the gain or profit of the employer; but to ensure fairness is established in the workplace. ${ }^{98}$ Unfortunately employers see cancer as deterrence for them in their profit-making ventures. However, this should not be the position at all because a balance must be maintained between the gains of the company and the rights of employees; which in turn will result in a healthy company that will be profitable for all stakeholders. Furthermore, maintaining a balance between the gains of the company and the rights of employees will also assist the employer in providing all the necessary support and making reasonable accommodation in the workplace to enable the employee to perform his or her duties well, as required by law. ${ }^{99}$ A balance between the gains of the company and the rights of employees will dispel the myth or stigma that is attached to cancer, namely that those diagnosed with cancer are incapable of working effectively and this can be achieved through effective communication and support from the employers side. ${ }^{100}$

Witzel argues that the demotion of an employee in the workplace for a reason such as cancer must be taken as a last resort and thought out carefully on how to execute it in line with the operational requirements of the company, in order to avoid legal proceedings being instituted by

94 MEC for Education, Kwazulu Natal v Pillay supra.

95 MEC for Education, Kwazulu Natal v Pillay supra.

96 Bernard 2014 (17) PER/PELJ 2881.

97 CANSA http://www.cansa.org.za/letter-to-corporates-world-cancer-day-4-feb -2014/ (accessed 2014-03-22).

98 Brassey et al, 99.

99 S 15(2) of the Employment Equity Act 55 of 1998, makes provision for the employer to make means in the workplace through adjusting the working conditions in such a way as to accommodate the cancer survivor who has returned to work and who cannot perform his or her duties than before; due to the adverse effect of cancer treatment.

100 CANSA-http://www.cansa.org.za/letter-to-corporates-world-cancer-day-4-feb -2014/ (accessed 2014-03-22). 
the employee concerned. ${ }^{101}$ Witzel goes further to support her assertions about how demotions must be exercised diligently, because companies demote employees with the aim of avoiding the severity of completely firing the employee concerned. ${ }^{102}$ Witzel correctly states that the demotion of an employee can be justified on the part of an employer, if the employer demotes a good employee in trying to retain them in circumstances where the particular employee cannot remain in the current position, due to issues such as the inherent requirements of the job, such as the core activities or skills of the relevant job position. ${ }^{103}$

Willey takes the views of Witzel a step further by putting emphasis on how demotion must be handled in the workplace, and he argues that it must be done with grace as well as with respect. According to Willey, open communication between the employer and the employees about the grounds of demotion as well as encouraging the concerned employee to improve on his or her performance will result in no claim for unfair labour practices on the part of the employee. ${ }^{104}$ This approach may leave the employee concerned still feeling attached to the company despite the demotion, and may also encourage the employee to improve where he or she has been lacking competence. However, this is unfortunately not the case when cancer employees are demoted as they are left emotionally aggrieved, due to lack of communication, as outlined in the previous paragraph.

Therefore, it is clear that demotion can amount to unfair labour practice, but it can also be justifiable if it is found to be in the interests of the company to do so. The process of handling demotion must be open, taking into account that the employee has the right to human dignity and respect. This clearly affirms that an employee with cancer who has been demoted on the basis of the inherent requirements of the job, and with the aim of retaining them through an open and transparent process which does not violate any of their human rights, can improve and contribute to the well-being of both the cancer employee and the company.

It is positive law that if an employer fails to carry out his or her duties in terms of the employment contract, the employee will have recourse to approach either the CCMA or the labour court on the basis of breach of contract. ${ }^{105}$ Therefore, in the context of this study, a cancer employee can have recourse against the employer in cases were the employer fails to treat all employees equally and fairly, by way of directing unfair

101 Operational requirement means the technological, structural or similar needs of the employer to justify dismissal of an employee. Please refer to Witzel Origins of the World's Myths (2013) 21.

102 Witzel 22.

103 Willey available at http://www.workforce.com/articles/21366-dealing-withdemotions-from-hrs-perspective (accessed 2016-05-16).

104 Willey available at http://www.workforce.com/articles/21366-dealing-withdemotions-from-hrs-perspective (accessed 2016-05-16).

105 S 191(1) of the Labour Relations Act 66 of 1995. 
treatment towards the cancer employee on the basis of his or her condition. In this case the cancer employee will have two forms of recourse. On the one hand, the employee can claim breach of contract on the basis that the employer has failed to discharge his or her duties by not treating all employees equally in accordance with the provisions of Basic Condition of Employment Act; ${ }^{106}$ and on the other hand, the cancer employee will have recourse on the basis of section 6(1) of the Employment Equity Act, ${ }^{107}$ which prohibits employers from engaging in any form of unfair discrimination in the workplace.

\section{Comparative analysis between South Africa, England and the United States of America}

Owing to some historical connections and some commonalities between the South African and English legal systems, an assessment of relevant laws may be instructive for South Africa. ${ }^{108}$ The comparative analysis is aimed at seeing whether the English law position may reveal some improvements that can be made to existing laws and policies in South Africa, with regards to the legal protection of cancer employees against unfair discrimination and other social ills.

As far as English law is concerned, the Equality Act of 2010 provides protective measures that also apply to cancer patients in employment contexts, offering protection from unfair discrimination, which they may experience on the basis of their health status. ${ }^{109}$ The Equality Act has put England ahead of South Africa by making special provision for the protection of cancer patients and recognising cancer as a progressive medical condition which can result in a disability. ${ }^{110}$

However, a discussion about the challenges facing cancer employees in the workplace would not be complete without reference to the American system. ${ }^{111}$ Some valuable lessons can be drawn from its jurisprudence when it comes to the protection of cancer employees in the workplace because America has flexible legal instruments in place. One relevant example here is the Americans with Disabilities Amendment Act (ADAA) of 2008, which is described as a very important piece of legislation aimed towards the protection of people who suffer from disabilities, which include cancer. ${ }^{112}$

106 S 10 of the Basic Condition of Employment Act 75 of 1997.

107 S 6(1) of the Employment Equity Act 55 of 1998.

108 Joubert WA (ed) LAWSA (2004) 8-9.

109 Equality Act of 2010.

$110 \mathrm{~S} 3$ of the Equality Act of 2010.

111 Russell "Sickness Absence and Disability Discrimination" 2013 TUC 4.

112 Russell 2013 TUC 5. 


\section{The protection of employees with cancer in England and the Equality Act of 2010}

Discrimination towards employees with cancer in England has been rising steadily over the past few years, as some of these cancer-stricken employees may be denied sick leave and consequently may miss some of their doctor's appointments. ${ }^{113}$ Employees with cancer are often harassed by employers and fellow employees to an extent where they feel like abandoning their jobs. ${ }^{114}$ The British government has thus identified a number of considerations which can assist cancer employees to be fully rehabilitated and capable of returning to work after being diagnosed with cancer. ${ }^{115}$ Among other things, these include; providing fast and cost effective treatment to cancer employees, providing personal and psychological agencies to cancer employees in helping them to cope with cancer symptoms in order to build self-confidence regarding their ability and skills to work; providing empowerment to the employee to set achievable goals which will boost their self-confidence; having the employer modify the workplace for the employee returning to work in order to assist the employee to perform his or her duties. ${ }^{116}$

Over 100000 people of working age are diagnosed with cancer every year in England, ${ }^{117}$ and almost half of these people continue to work when they are diagnosed with cancer and have to make changes to their working habits; with around four out of ten of them changing jobs or leaving work altogether due to the unfair discrimination in the workplace. ${ }^{118}$ Some of the injustices

113 Bailey and Corner Cancer Nursing Care in Context (2009) 623.

114 Devane 2013 Macmillian Cancer Support 11.

115 Devane 2013 Macmillian Cancer Support 12.

116 Devane 2013 Macmillian Cancer Support 13.

117 Blanpain The Changing World of Work (2009) 24, and please refer to Krebs and Pelusi "Understanding Cancer-Understanding the Stories of Life and Living” 2015 JCE 12.

118 Hope 2013-05-02 Mail Online 2. Examples of the two incidences in which cancer employees suffered unfair discrimination in the workplace in England owing to their cancer include: In 2006 a designer and studio manager never got the justice that he deserved due to the injustices he suffered in the hands of the employer. Jack had colon cancer that resulted in him being unfairly discriminated against by the employer. The employer refused Jack time off, he constantly reduced his salary when he was not at work; though he was working from home; took away some of his responsibilities, harassed him and constantly abused him verbally. All of this occurred despite the commitment of Jack working day and night and additionally, working at home, which led to unrecognised efforts. When Jack approached management for assistance he was informed that he can sell his house or car to comply with his medical bills. Owing to the depression, ailing health, financial and work stress which Jack had endured; he died on his way to work. Another unfair discrimination case of cancer in the workplace occurred in 2010. A man by the name of Paul Ware, who was diagnosed with blood cancer, asked for time off from the employer and as a result, his employment was terminated. The employer reasoned that he was not fully committed to the company as a result of his cancer. He questioned this decision in the equality court, but due to expensive legal costs, he was forced to accept a settlement from the employer, which was very low. 
that employees face as a result of cancer include how they tend to not be allowed some time off from work in order to see their doctors. ${ }^{119}$ This has resulted in the government providing effective treatment mechanisms to cancer patients, with the aim of alleviating discrimination in order for cancer employees to return to work and not require further time off or reasonable accommodation. ${ }^{120}$ It is important for employees with cancer to, as far as possible, continue to work and earn a living. Blanpain describes the importance of work in the life of any human being and further states that: Work is a fundamental aspect in the life of any person, it gives the individual means of financial support and most importantly, it gives one a contributory role to society. A person's work is an essential component of his or her sense of identity, self-worth, and emotional well-being. Accordingly, the working conditions where a person works are very important in shaping or developing the whole compendium of psychological, emotional and physical elements of a person's dignity and self-respect. ${ }^{121}$

Considering the importance of employment in the general make up of any human being, it is important that the right to work for cancer employees be protected through legislative reform, amongst others; for purposes of their survival in both society and in the workplace. Furthermore, the government developed means to protect disabled employees and cancer employees in the workplace from unfair discrimination. ${ }^{122}$ In England, cancer is recognised as a progressive condition which could result in a disability and thus render an employee suffering from cancer to be regarded and protected as a disabled employee. ${ }^{123}$

In contrast, South Africa has not yet developed a framework recognising cancer management in the workplace. It is in this regard that South Africa should take note of the developments in England in improving the current situation. ${ }^{124}$

The aim of the Equality Act ${ }^{125}$ is to bring harmonisation, simplification and modernisation of equality laws, through the express declaration that every human being is entitled to equal protection and benefit under the

119 Bailey and Corner 624

120 Bailey and Corner 624.

121 Blanpain 23

122 Krebs and Pelusi 2015 JCE 13.

123 Krebs and Pelusi 2015 JCE 14

124 Krebs and Pelusi 2015 JCE 15.

125 Equality Act 2010. This is the Act that seeks to take away any form of discrimination which people suffering from disability can experience on the hands of other people such as the employer. The Disability Discrimination Act 1995 (DDA) is important to take into account, as it was one of the first pieces of legislation in England that was used to fight unfair discrimination on the basis of disability in the workplace. The Disability Discrimination Act 1995 was replaced in 2005; but finally in 2010 the Equality Act 2010 was developed which is considered as a combination of various pieces of legislation which fight unfair discrimination in one legislation. According to the Equality Act 2010, cancer is recognised as a disability and all people with cancer are protected by this legislation. 
law regardless of their background or social being. ${ }^{126}$ The Equality Act makes provision for protective feature under section 4 , which include age, disability, gender reassignment, marriage and civil partnership, pregnancy and maternity, race, religion or belief, sex and sexual orientation. ${ }^{127}$ Hepple, ${ }^{128}$ argues that the reason why the Equality Act provides a specific list of prohibited grounds of discrimination is because the open-ended approach to defining the prohibited grounds is subject to abuse and criticism. It is argued that such an approach, as adopted by the European Convention on Human Rights, is not clear and specific. ${ }^{129}$

Hepple's view is correct because having a specific list of prohibited grounds makes it easy for people to immediately know and understand their rights, and it gives them certainty without having first to make an inquiry regarding the interpretation of the law in order to establish the rights to which they are entitled. Similar to the position in England, South African law also makes provision for the prohibition of discrimination on the basis of the grounds which have also been outlined in terms of the Equality Act, through section 9 (e.g the equality clause) of the Constitution. 130 The understanding of "disability", however, differs in these two jurisdictions. In terms of section 6 of the Equality Act, ${ }^{131}$ in England a person is said to have a disability if he or she has a physical or

$126 \mathrm{~S} 2$ of the Equality Act 2010. The importance and broad scope of the Equality Act as outlined above is affirmed by the reasoning of Ashtiany, who argued that the Equality Act is one of the pieces of legislation that makes England one of the progressive countries across the globe. This is attributed to the fact that the Equality Act is a codification and simplification of existing laws because it brings together 9 major pieces of legislation and around 100 statutory instruments. Ashtiany further argues that the reach of the Equality Act is far greater than the codification and simplification of existing laws, because the intention of this Act is to bring together a coherent set of provisions for the $21^{\text {st }}$ century and to enhance the existing law at the same time. This argument is indeed correct because this Act makes provision for the rights of all people in spite of their socioeconomic status, disability or ill health because that aim of this Act is to attain equality as outlined in the purpose of the Act. See Ashtiany "The Equality Act 2010: Main Concepts” 2011 IJDL 29-30.

$127 \mathrm{~S} 4$ of the Equality Act 2010.

128 Equality Act 2010. This is the Act that seeks to take away any form of discrimination which people suffering from disability can experience on the hands of other people such as the employer. The Disability Discrimination Act 1995 (DDA) is important to take into account, as it was one of the first pieces of legislation in England that was used to fight unfair discrimination on the basis of disability in the workplace. The Disability Discrimination Act 1995 was replaced in 2005; but finally in 2010 the Equality Act 2010 was developed which is considered as a combination of various pieces of legislation, which fight unfair discrimination in one legislation. According to the Equality Act 2010, cancer is recognised as a disability and all people with cancer are protected by this legislation.

129 Hepple "The New Single Equality Act in Britain" 2010 TERR 12.

130 S 9(3) of the Constitution of the Republic of South Africa, 1996 states that the state may not unfairly discriminate directly or indirectly against anyone on one or more grounds including race, gender, sexual orientation, sec, age, religion, belief, disability, culture, language and birth.

131 S 6 of the Equality Act 2010. 
mental impairment and the impairment has a substantial and long term adverse effect on the person's ability to carry out normal day to day activities. ${ }^{132}$ This definition of disability was taken further by the British Council Organisations for Disabled people, an organisation which champions for the rights of disabled people in society. ${ }^{133}$ In terms of the British Council of Organisations for Disabled People, disability is defined as "the disadvantage or restriction of activity caused by a society which takes little or no account of people who have impairments and thus excludes them from mainstream activities". 134

In terms of the UN Convention on the Rights of Persons with Disabilities, it is argued that a disability is an evolving concept which is not stagnant; and therefore has to be accommodated by the adaptation of legislation. ${ }^{135}$ The Convention states that since the definition of a disability is evolving, it must not be seen as something that resides within an individual as a result of his or her impairment. Disability must be understood within the context of the interaction between an individual with his or her environment. ${ }^{136}$ This understanding is supported and recommended in this paper, because health conditions such as cancer may lead to disability, because of the impact cancer may have on the individual's interaction with his or her environment, and more specifically, the workplace.

132 S 6(1)(a)-(b) of the Equality Act 2010. The aspect of a substantive and adverse effect was also discussed in the court case of Swift $v$ Chief Constable of Wiltshire, SCA Packaging Ltd v Boyle HL 2009. In this case the court made an inquiry as to what constitutes a substantive and adverse effect which could have an impact on the ability of an employee to continue or do work, and the court held that the following questions needs to be answered in the affirmative for the condition of one to be recognised as a disability that has the ability to substantively and adversely affect the ability of an employee to do work. Firstly, was there impairment on the employee? Did the impairment have a substantial adverse effect on the ability of the employee to do work? Did the adverse effect cease to have a substantial adverse effect on the ability of the employee to continue to do work and if so, when was this? Lastly, an inquiry will deal with the aspect as to whether the same adverse effect on the employee is likely to occur again in the near future.

133 The British Council was established in 2006 as an advisory body with the aim of protecting and championing the rights of disabled people due to the hostile environment they experience in the workplace through discrimination. This Organisation has grown incredibly and has committed staff members that are well qualified and it provides guidance as well as advice to employers and government as to how employees who suffer from disability need to be treated and protected from unfair discrimination. Please refer to the British Council guide on promoting disability equality (2009) 11.

134 British Council of Organisations of Disabled People British Council guide on promoting disability equality http://britishcouncil.org/sites/default/files/pro moting_disability_equality.doc (accessed 2016-08-22).

135 Hendricks "Selected Legislation and Jurisprudence: UN Convention on the Rights of Persons with Disabilities" 2007 Eur. J. Health. L 273.

136 Hendricks 2007 Eur. J. Health. L 274. 


\section{The protection of employees with cancer in the United States of America and the Americans with Disabilities Amendment Act (ADDA) of 2008}

More than 800000 people are diagnosed with cancer every year in America, and of this number approximately 400000 will be cured of the cancer. ${ }^{137}$ The American Cancer Society states that $90 \%$ of employees with cancer face discrimination in the workplace due to the employers' ignorance regarding cancer. ${ }^{138}$ This confirms the view that the struggle of cancer survivors follows them from the hospital into the workplace. ${ }^{39}$ Cancer employees experience different forms of discrimination in the workplace, which may include job denial, wage reduction, denial of a promotion and outright dismissal. ${ }^{140}$

In the United States, employers often justify their conduct of discrimination by ignorantly arguing that cancer is contagious, and that

137 Streicher "Cancer-Based Employment Discrimination: Whether the Proposed Amendment to Title VII Will Provide An Effective AntiDiscrimination Remedy" 2010 Ind.L.J 827. Furthermore, in America the position regarding the protection of cancer patients generally, and cancer employees in particular, was best described by Professor Epstein, who was a scientist in the field of medicine. According to Epstein, cancer remains one of the deadliest diseases known to mankind across the globe; and beyond the millions of lives which are claimed by cancer, millions of more people live in fear of being diagnosed with the disease. This is all attributed to the stigma and less investment that is placed on cancer research and treatment by governments across the globe, including the United States of America. Epstein, in collaboration with some of his colleagues in the medical field argued for a more aggressive approach or assault when it comes to the preventable causes of cancer that people are unknowingly exposed to daily, especially at home and in the working environment. These causes of cancer which people are often exposed to, result in socioeconomic problems which cancer patients experience because they end up unemployed as a result of the cancer. This can result in a dent on the economy of the state due to the high rise of unemployment. The analogy of Epstein has resulted in making the American government to take heed of the cancer epidemic and to device the necessary legislation, in particular the Americans with Disabilities Amended Act, with the aim of protecting the rights of cancer patients, in particular cancer employees against unfair discrimination in the workplace. This is to dispel the myths as well as the stigma that is surrounds the area of cancer. Please refer to Epstein CancerGate: How to Win the Losing Cancer War (2005) 5. In this book Epstein provides an analysis of the American struggle against cancer, in relation to reducing the incidence and mortality rate, and he proposes a complex strategy on how to fight the war against cancer. It is currently evident in the American system, that the contribution made by Epstein when it comes to the fight against cancer is recognised by the government and as a result of this, America today has made great strides when it comes to cancer regulation.

138 Streicher 2010 Ind.L.J 827-828.

139 More cancer survivors return to work after being diagnosed with cancer but will be subjected to discrimination and their ability to work questioned by employers due to their cancer. See Bazamore "Employment Discrimination against Cancer Survivors: A Proposed Solution" 2001 Vill. L.Rev 1550.

140 Streicher 2010 Ind.L.J 827-829. 
other employees will not be keen to work with a cancer employee; in addition to arguing that a cancer employee will be unproductive and will thus be a liability to the company. ${ }^{141}$ All of these arguments were revealed to be unfounded and based on incorrect perceptions or ignorance. ${ }^{142}$ Employees with cancer in South Africa suffer from similar types of discrimination in the workplace, and the justifications of employers resemble those of some of the English employers. This indicates that false perceptions and ignorance regarding cancer are shared by employers across the world alike. The need for legal intervention to address these perceptions and their harmful impact is evident.

Much focus has been placed on this area of the law in America. Section 3 of the Americans with Disabilities Amendment Act (ADAA), defines disability as a physical or mental impairment that substantially limits one or more major life activities of an individual, and a record of such impairment is necessary for the purpose of this Act, in order to be considered as a disability. ${ }^{143}$ Further, section $3(2)$ of the Amended Americans with Disabilities Act states that, major life activities for the purposes of this Act include operation of a major bodily function; including but not limited to the functions of the immune system; normal cell growth; digestive; bowel; bladder; neurological; brain; respiratory; circulatory; endocrine, and reproductive functions. ${ }^{144}$

Benfer argues that the definition of the term substantially limits the rights of disabled persons and should be given a broader interpretation as intended by the Americans with Disabilities Amendment Act. ${ }^{145}$ Such a broad interpretation will allow a number of chronic diseases, which can cause disability to be incorporated under the category of disability. ${ }^{146}$ Benfer provides a list of chronic diseases, which can substantially limit the ability of an individual to work, and those which are recognised by the Americans with Disabilities Amendment Act such as cerebral palsy, HIV/AIDS, Hepatitis B and cancer. ${ }^{147}$

Benfer correctly advances an argument which leads to cancer being recognised as a disability in terms of the Americans with Disabilities Amendment Act. ${ }^{148}$ This is evident from the court case of Ellison $v$ Software Company. ${ }^{149}$ Miss Ellison was an employee of the defendant company and had breast cancer. She had surgery and was required to go

141 Canfield "Cancer Patients Prognosis: How Terminal are their Employment Prospects?” 2001 Syracuse Law Review 801.

142 Wheatly "Employability of Persons with a History of Treatment of Cancer" 1975 CANCER 441.

$143 \mathrm{~S} 3$ of the Amended Americans with Disabilities Act of 2008.

144 S 3(2) of the Amended Americans with Disabilities Act of 2008.

145 Benfer "The American with Disabilities Amendment Act: An overview of recent changes to the American with Disabilities Act" 2009 ASC 6.

146 Benfer 2009 ASC 6.

147 Benfer 2009 ASC 6.

148 Benfer 2009 ASC 7.

149 Ellison $v$ Software Company, Inc, 85 F3d 187 (5th Cir. 1996). 
for radiation six days a week as part of her treatment, which caused her to go to work late on a daily basis. This however, did not prevent her from executing her duties in the company because she worked during her lunch breaks and often left the office late in order to catch up with some work. During this period of receiving treatment, Miss Elliot received an unfavourable performance appraisal and she was told that she would be demoted; this is despite all the efforts she has put in ensuring that her work was up to date. ${ }^{150}$ She was later dismissed by the employer, and she brought a claim against the employer to assert that she has been unfairly discriminated against on the basis of her suffering from cancer; which amounted to a disability.

The court dismissed her claim on the basis that cancer does not amount to disability in terms of the then Americans with Disabilities Act of 1990 (ADA), which was replaced by the current legislation of Americans with Disabilities Amendment Act. ${ }^{151}$ In determining whether a person with cancer is indeed disabled, a court must consider cancer in its active state, whether or not an individual is in remission. ${ }^{152}$ This decision by the court was widely criticised because it excluded cancer employees from the protection of the law. Employers discriminated against cancer employees in America, and the ignorant belief of cancer being contagious made it worse for cancer employees to even finding employment. ${ }^{153}$ The impact of this is that employers may tend to view cancer employees as liabilities, because they are likely to become ill at work, perform poorly and also to be absent frequently or all the time. ${ }^{154}$ Such harsh treatment towards cancer employees constitutes a violation of their basic human rights, because work has been an important component of the survival of human beings from the beginning of time. 155

Morrell, ${ }^{156}$ correctly states that work is a symbol of independence, competence and accomplishment which any human being desires on earth, because work does not only provide for the needs of physical desires in order to survive but work actually serves as a means to define one's self or establish one's sense of worth in life. In the context of

150 Ellison $v$ Software Company, supra.

151 Ellison $v$ Software Company, supra.

152 S 3 of the Amended Americans with Disabilities Act of 2008.

153 Morrell "Aids and Cancer: Critical employment discrimination issues" 1990 J.Corp.L 851

154 Morrell 1990 J.Corp.L851.

155 Feldman M Wellness and Work, in Psychosocial stress and cancer (2000) 173.

156 Morrell 1990 J.Corp.L855. Further, please refer to Wheatley "The Employability of Persons with a History of Cancer 1974 CANCER 441-445, in this article Wheatley provides that a Metropolitan Life Insurance Company did a study of its employees who were known to have cancer and confirmed that the work performance of employees with cancer is nearly similar to the work performance of employees without cancer. The company concluded that cancer employees were excellent employees and this is when Wheatley argues that, for cancer employees to thrive in the workplace they must be given an opportunity and provided with all the necessary support in the workplace. 
cancer, it has been argued earlier in the study that work actually forms part and parcel of the healing process of the cancer employee. Excluding them from working actually means taking away their self-worth and basic human rights as asserted by Morrell.

As will be seen from the cases referred to below, some of the US cases dismissed the claims of cancer employees on the ground that cancer is not a disability.

For example, in Lynos $v$ Heritage House Restaurant Inc, ${ }^{157}$ the employee, a kitchen manager of the employer, who was diagnosed with cancer of the uterus, was dismissed by her employer after her medical condition became known. She then brought a claim against the employer on the basis of unfair discrimination due to her medical condition i.e. cancer, asserting that her condition amounted to a disability. ${ }^{158}$ The employee argued that despite being diagnosed with cancer, she was still efficient and capable to do her work without any problems. The court, however, dismissed her application and ruled in favour of the employer. The reasoning of the court was that the applicant was not disabled or handicapped because she was still able to do her work and cancer does not amount to disability in terms of the law. ${ }^{159}$

Korn, ${ }^{160}$ argued that the problem with cancer is that it has compounded issues which society in general and the legal system in particular are not willing to discuss. ${ }^{161}$ This is due to the fact that society views disability as a static physical problem and cancer unfortunately does not fit into that pattern. In its active state, cancer substantially limits the normal cell growth function and thus an individual with cancer is protected by the Americans with Disabilities Amendment Act. ${ }^{162}$ Korn asserts that cancer is viewed in a similar dichotomous manner, in the sense that we think that a person with cancer will most probably die and less likely to be cured, and this is a wrong perception. ${ }^{163}$ From the Elliot case and the arguments presented by Korn, it is clear that at some point in the American jurisprudence there was a denial and exclusion of cancer patients from the protection of the law, which resulted in unfair discrimination of cancer patients and employees. This example may be compared to the situation in some African countries where HIV/AIDS denial led to devastating consequences, and millions of lives lost in the process. ${ }^{164}$

Scott, ${ }^{165}$ believes that this definition of disability by the Americans with Disabilities Amendment Act restored the definition of disability of

157 Lynos $v$ Heritage House Restaurant Inc 89 III App NE 270 (1982).

158 Lynos $v$ Heritage House Restaurant Inc supra.

159 Lynos $v$ Heritage House Restaurant Inc supra.

160 Korn 2001 S. Cal L Rev 400.

161 Korn 2001 S. Cal L Rev 401.

162 Benfer 2009 ASC 13.

163 Korn 2001 S. Cal L Rev 404.

164 Nattras “Aids Denialism vs Science” 2007 Sketical Inquiry 109.

165 Scott Principles and Applications of Assessment in Counselling (2013) 314. 
the initial Americans with Disability Act of 1990, while at the same time broadening the definition of disability to include both physical and mental impairment which can render a person disabled. He further argues that this approach of including both the physical and mental impairment will be of great benefit for the people, as many people will be protected from being unfairly discriminated against by both employers and society. ${ }^{166}$ One can surely attest to this argument that such a flexible definition of disability is one that is required in South Africa, where disability is still mainly dependent on the physical impairment of the patient.

Incorporating a flexible definition of disability which recognises both mental and physical impairments which substantially limit the ability of the patient or employee in the South African jurisprudence will be helpful in broadly covering different types of deformities. This approach may assist to correct the problem created in our law by the recognition of some health conditions, for example, the recognition of HIV/AIDS as a disability, while leaving behind health conditions such as cancer which can have the same or more adverse effects than HIV/AIDS. This flexible approach may potentially rule out the unfair operation of our employment laws for cancer employees, as cancer can either render a person temporarily or permanently disabled, and thus in need of legal protection in the workplace. ${ }^{167}$

The Americans with Disabilities Amendment Act regards cancer as a disability in instances where it substantially limits the ability of an individual to do daily activities or if at some point the cancer limited the ability of an individual to do daily activities. ${ }^{168}$ Whether an individual employee will be covered by the provisions of the Americans with Disabilities Amendment Act is a question of fact and is determined on a case by case basis. A cancer employee who does not experience a substantial limit of their ability to do daily activities will not be deemed to have a disability. From this reasoning, it is apparent that in the American context, cancer will constitute as a disability if it has an effect or impact on the ability of the individual to do daily activities. Moreover, it is also clear that a diagnosis of cancer does not automatically render a cancer patient as a person who suffers from a disability.

166 Scott 315. Furthermore one can argue that these assertions by Scott resemble or take into context what Senator Tom Harkin said when the Americans with Disabilities Act was adopted in 1990. He stated that: "The ADA is based on a single premise that disability is a single natural part of human experience. Disability in no way diminishes the right of people to live independently, enjoy self-determination, make choices, pursue meaningful careers, and enjoy full inclusion and integration in the economic, political, social, cultural and educational mainstream of American society". See Harkin "The Americans with Disabilities Act: Four years later - commentary on blanck" 1994 IOWA.L.R 936.

167 Curtis et al, Glass Office Gynaecology (2014) 533.

168 S 3 of the Amended Americans with Disabilities Act of 2008. 


\section{Conclusion}

Cancer does not take away the human dignity and ability of employees with cancer, which is something that employers must learn and take into consideration. This understanding of the disease will be achieved through education and awareness of cancer, that can contribute to the development and amendment of workplace policies among other things and it will alleviate things such as unfair discrimination and unfair labour practices which come as a result of the stigma and ignorance that is attached to cancer not only in the workplace, but in society in general. 